\title{
Genetics of Moyamoya disease
}

\author{
Constantin Roder ${ }^{1}$, Nikhil R Nayak ${ }^{2}$, Nadia Khan ${ }^{3}$, Marcos Tatagiba ${ }^{1}$, Ituro Inoue ${ }^{4}$ and Boris Krischek ${ }^{1}$
}

Moyamoya disease (MMD) is a disease pattern consisting of bilateral stenosis of the intracranial internal carotid arteries (ICA) accompanied by a network of abnormal collateral vessels that bypass the stenosis. Once symptomatic, insufficient cerebral blood flow or rupture of the fragile collaterals may cause stroke or hemorrhage, resulting in severe neurological dysfunction or death. The etiology of MMD is still unknown, although few associations with other diseases and environmental factors have been described. Strong regional differences in epidemiological data, as well as known familial cases, turned the focus to genetics for the insight into the disease's pathogenesis. Thus far, several reports have suggested specific genetic loci and individual genes as predisposing to MMD, but none have demonstrated reproducible results in independent cohorts. Small sample sizes, as well as a likely multifactorial origin, seem to be the most challenging tasks in identifying the disease-causing mechanisms. Once identified, susceptibility genes may allow preventive screening and a possible development of novel therapeutic options. Journal of Human Genetics (2010) 55, 711-716; doi:10.1038/jhg.2010.103; published online 26 August 2010

Keywords: genetics; Moyamoya disease; stroke

In 1957 Takeuchi and Shimizu, ${ }^{1}$ demonstrated a peculiar angiographic presentation consisting of bilateral stenosis of the intracranial internal carotid arteries (ICA), beginning at the terminal segment with the formation of an abnormal vascular network of collateral vessels in the basal ganglia resembling 'a puff of smoke drifting in the air,' or 'moyamoya' in the Japanese language. In 1969, Suzuki and Takaku first categorized this disease as a new entity and named it Moyamoya disease (MMD), from its angiographical appearance. ${ }^{2}$

\section{DEFINITION}

Regarding the term 'Moyamoya', different disease entities should be clarified: 'Definite Moyamoya disease' is characterized by bilateral progressive stenosis or occlusion of the terminal segments of the ICA or proximal segments of the anterior or middle cerebral arteries, accompanied by abnormal vascular networks in the arterial territories near the occlusive or stenotic lesions; 'Probable Moyamoya disease' describes the unilateral appearance of pathological changes as described above; 'Moyamoya syndrome' is used for patients with known systemic diseases (such as autoimmune disease or Down syndrome, among others), who present with angiographic changes akin to those found in patients with MMD. ${ }^{3}$

\section{CLINICAL ASPECTS}

Two broad clinical manifestations of Moyamoya can be distinguished: juvenile Moyamoya (peak age at presentation 5-10 years) and adult Moyamoya (peak age at presentation 30-40 years). Moyamoya patients become symptomatic due to episodes of recurrent cerebral ischemia or complete stroke. The clinical symptoms vary widely and include, but are not limited to, headaches, recurrent transient ischemic attacks, epileptic seizures, or disturbances of speech and cognition. In cases of recurrent or chronic frontal ischemia, blunting of normal mental development may result. Ischemic symptoms are most common in the juvenile form of Moyamoya. Within adult Moyamoya cohorts, cerebral ischemia presents more often in Caucasian patients, whereas cerebral hemorrhage is the primary manifestation in Asian adult Moyamoya patients. Mortality can range from $2 \%$ in the acute infarct phase to $16 \%$ with intracerebral hemorrhage. ${ }^{4,5}$

\section{EPIDEMIOLOGY}

Epidemiological data show strong regional differences with a high occurrence in Asian countries (primarily Japan and Korea) and much smaller rates in western countries, making the reported prevalence and incidence quite variable. An incidence of approximately 1 per 100000 in Japan and 0.1 per 100000 in non-Asian countries is frequently cited in the literature. ${ }^{6-11}$ With a prevalence of 3 cases per 100000 children, MMD is known to be the most common pediatric cerebrovascular disease in Japan. ${ }^{12}$ MMD occurs more frequently in females, with a female to male ratio of $1.8: 1 .^{9}$

\section{TREATMENT}

The natural history of the disease is still not well described. The juvenile form appears to progress into puberty, thereafter stabilizing spontaneously. In all, $80 \%$ of such patients have a fairly benign course in terms of life expectancy regardless of surgery, but will typically experience significant neurological dysfunction. Children presenting with the disease before the age of 5 may suffer significant impairment

${ }^{1}$ Department of Neurosurgery, University of Tübingen, Tübingen, Germany; ${ }^{2}$ Department of Neurosurgery, University of Pennsylvania School of Medicine, Philadelphia, PA, USA; ${ }^{3}$ Department of Neurosurgery and Stanford Stroke Center, Stanford University School of Medicine, Stanford, CA, USA and ${ }^{4}$ Department of Molecular Life Sciences, Tokai University School of Medicine, Kanagawa, Japan

Correspondence: Dr B Krischek, Department of Neurosurgery, University of Tübingen, Hoppe-Seyler-Strasse 3, Tübingen 72076, Germany.

E-mail: krischek@gmail.com

Received 11 July 2010; revised 27 July 2010; accepted 28 July 2010; published online 26 August 2010 
in normal psychomotor development. Therefore, early detection and surgical management to augment cerebral perfusion by surgical revascularization procedures is essential. ${ }^{4,5}$ Direct extracranial-intracranial microanastomoses for revascularization in Moyamoya angiopathy is the method of choice in children with recalcitrant hemodynamic compromise after Diamox challenge. Several bilateral, direct bypass procedures for revascularization during a single surgery, as well as complex anastomoses to branches of the anterior cerebral artery have proven to be effective in preventing stroke. Indirect revascularization procedures (that is, arteriosynangiosis, durasynangiosis) are used as an adjunct or alternative to direct bypass in cases where donor or recipient arteries are unavailable or of inadequate calibre for the anastomosis. ${ }^{13-15}$ Medical therapies in MMD aim to prevent complications, such as antiplatelets to prevent microthrombi, or to treat symptoms, such as calcium-channel blockers to alleviate severe headaches. However, no study has yet demonstrated a statistically significant improvement in patient outcomes using medical therapy. ${ }^{12}$

\section{PATHOLOGY}

Histopathological analyses have demonstrated that fibrocellular thickening of the intima, an irregular disruption of the internal elastic lamina, and the attenuation of the media in the ICA and branches of the circle of Willis are the predominant microscopic findings in the stenotic vessels. ${ }^{16}$ The small Moyamoya collaterals characteristically have thinned media layers, fragmented elastic lamina and microaneurysms, which are believed to be responsible for hemorrhagic events in patients with MMD. ${ }^{12}$

\section{ETIOLOGY}

The etiology of MMD is still unknown. In the search for a better understanding of the pathogenesis of MMD, three major approaches may be considered: idiopathic, environmental or genetic causes, or a combination of any of the three. Environmental factors may have a role, but little evidence is supplied in the literature. A possible association was published by Ullich et al., ${ }^{17}$ which showed a higher prevalence of MMD in 60 children after therapeutic brain radiation. Moreover, cases with previous infection in the head and neck region have been reported to be at higher risk of developing MMD. ${ }^{18}$ More recently, genetic approaches have become increasingly utilized to shed light on the disease pathogenesis. Evidence for a genetic contribution to MMD is suggested by the highly variable incidence rates between different ethnic groups, as described above, as well as the many familial occurrences described in the literature. Familial cases account for $9-15 \%$ of all cases, ${ }^{19-21}$ and within this group the epidemiological data change: ${ }^{22,23}$ The female to male ratio rises from 1.6:1 in sporadic cases to 5:1 in familial cases; the mean age of onset drops from 30 years in sporadic to 11.8 years in familial cases; the onset of symptoms in parents of affected families shows an average of 30.7 years, whereas their offspring show the first signs of Moyamoya at an average age of 7.2 years. MMD has also been reported in patients with other diseases of known genetic origin, such as neurofibromatosis type I and Down syndrome, among others, highlighting the evidence for a possible genetic etiology for this severe disease. ${ }^{22-24}$

\section{GENETIC STUDIES}

Many studies have been published implicating certain genetic loci to harbor risk loci for developing MMD, however, none of these findings have been replicated in independent cohorts. The main genetic approaches utilized have been linkage analyses to locate susceptibility loci in affected families and association studies with a case-control study design. For this review, all types of genetic studies on MMD published to date were collected and the results are presented chronologically (Table 1).

The first genetic study on MMD was performed by Inoue et al. in $1997 .{ }^{25}$ Their work was based on previous studies that suggested the association of human leukocyte antigens (HLA) and MMD by serological screening. The authors genotyped HLA gene alleles (class I: HLA-A; class II: HLA-DRB1, DQA1, DQB1, DPA1, DPB1) in 71 unrelated Japanese patients with MMD versus 525 healthy controls using the PCR-sequence specific oligonucleotide probe. HLA genes are located on chromosome $6 \mathrm{p} 21.3$. The results showed a positive disease association for $D Q B 1^{\star} 0502$ (phenotype frequency: $10 \%$ in patients versus $3 \%$ in controls; $\chi^{2}=5.485$; relative risk $\left.=3.27 ; P<0.025\right)$ and negative association for $D R B 1^{\star} 0405$ (phenotype frequency: $11 \%$ in patients versus $27 \%$ in controls; $\chi^{2}=7.142$; relative risk $=0.35$; $P<0.01$ ), as well as $D Q B 1^{\star} 0401$ (phenotype frequency: $13 \%$ in patients versus $26 \%$ in controls; $\chi^{2}=5.663$; relative risk $=0.40$; $P<0.025)$. Furthermore, differences in association were found after sub-dividing the cohort into early-onset and late-onset groups, as well as in the analysis of combined DR-DQ haplotype frequencies.

In 1999, Ikeda et al. ${ }^{26}$ accomplished a 'total genome search' with the DNA of 16 families (77 members, 28 males and 49 females, 37 with MMD) from Japan. The first stage with eight families covered 371 polymorphic microsatellite markers spanning all 22 autosomes. Twopoint logarithm of odds (LOD) scores were calculated under the assumption of either autosomal recessive inheritance or autosomal dominant inheritance (incomplete penetrance). The findings showed a LOD score $>1$ at the markers D3S2387 $(\mathrm{LOD}=1.493576$ at a recombination fraction of 0.1 (nonparametric LOD score 2.31, information content 0.848$)$ ) and $D 3 S 3050(\mathrm{LOD}=3.184154$ at a recombination fraction of 0.01 (nonparametric LOD score 1.80, information content 0.892$)$ ). Nonparametric linkage analysis showed a nonparametric LOD score of 11.96 at loci between D3S2387 and D3S3050 and an information content of $0.785-0.892$. Both markers are located on chromosome 3p24.2-p26. For the second stage with the other eight families, four markers (D3S2387, D3S3050,D3S1560 and D3S1304) at 3p24.2-p26 were used. A nonparametric analysis in this study revealed significant linkage at marker D3S3050 (nonparametric LOD score 3.46, information content 0.851 ). The region 3p24.2-p26 contains genes associated with Marfan syndrome, a syndrome characterized by weakness of the connective tissue fibrillin, and von Hippel-Lindau syndrome, a syndrome associated with hemangioblastomas, ${ }^{27,28}$ making this region of particular interest concerning the formation and maintenance of vessel walls.

In previous studies, an association was found between HLA and MMD by Inoue et al. ${ }^{29}$ To further investigate, a linkage study with 15 microsatellite markers on chromosome 6 , where the HLA complex is located, was performed with 20 affected Japanese siblings and their families. ${ }^{30}$ All patients were Japanese individuals who were diagnosed with definite MMD. The marker D6S441 on chromosome 6 showed positive linkage with an identity-by-descent value of zero for none of the sibling pairs, which means at least one allele was shared: the value one for 12 sibling pairs and two for eight sibling pairs (identity-bydescent: 0:12:8). Sharing of the identical allele was evaluated in 19 families, in terms of the haplotype. In 16 of these 19 families (82\%), D6S441 was shared between the affected members; in two families, it was not. Sharing of the allele could not be determined in one family because of low heterozygosity.

Yamauchi et al. ${ }^{31}$ assumed an association between the gene for neurofibromatosis type $\mathrm{I}^{32}$ on chromosome 17q11.2 and MMD, as the appearance of MMD in patients with neurofibromatosis type I has 
Table 1 Overview of genetic studies on Moyamoya Disease

\begin{tabular}{|c|c|c|c|c|c|c|c|c|}
\hline Author & Samples & Ethnicity & Type of study & Coverage & $\begin{array}{l}\text { Findings on } \\
\text { chromosome }\end{array}$ & Finding/marker & Result & Involved genes \\
\hline $\begin{array}{l}\text { Inoue } \\
\text { et al. } 25,29\end{array}$ & $\begin{array}{l}71 \text { Unrelated } \\
\text { patients with } \\
\text { MMD versus } \\
525 \text { healthy } \\
\text { controls }\end{array}$ & Japanese & HLA genotyping & $\begin{array}{l}\text { HLA alleles: } \\
\text { class I: HLA-A, } \\
\text { class II: HLA-DRB1, } \\
\text { DQA1, DQB1, } \\
\text { DPA1, DPB1 }\end{array}$ & $6 p 21.3$ & $\begin{array}{l}\text { DQB } 1 * 0502 \\
\text { DRB } 1 * 0405 \\
\text { DQB } 1 * 0401\end{array}$ & $\begin{array}{l}\text { DQB } 1 * 0502 \\
\text { (positive association), } \\
\text { DRB } 1 * 0405 \\
\text { (negative association), } \\
\text { DQB } 1 * 0401 \\
\text { (negative association) }\end{array}$ & HLA complex \\
\hline $\begin{array}{l}\text { Ikeda } \\
\text { et al. }\end{array}$ & $\begin{array}{l}37 \text { Affected } \\
\text { persons out } \\
\text { of } 16 \text { families }\end{array}$ & Japanese & Linkage analysis & $\begin{array}{l}\text { Total genome search } \\
\text { for } 371 \text { polymorphic } \\
\text { microsatellite } \\
\text { markers spanning } \\
\text { all } 22 \text { autosomes }\end{array}$ & 3p24.2-p26 & D3S3050 & NPL score 3.46 & $\begin{array}{l}\text { Marfan syndrome, } \\
\text { Hippel-Lindau } \\
\text { syndrome }\end{array}$ \\
\hline $\begin{array}{l}\text { Inoue } \\
\text { et al. }{ }^{30}\end{array}$ & $\begin{array}{l}20 \text { Affected } \\
\text { sibling pairs } \\
\text { and their } \\
\text { families }\end{array}$ & Japanese & Linkage analysis & $\begin{array}{l}15 \text { Microsatellite } \\
\text { markers on } \\
\text { chromosome } 6\end{array}$ & $6 q 25$ & D6S441 & $\begin{array}{l}\text { IBD: } 0: 12: 8 \text {; shared } \\
\text { haplotype among } \\
16 \text { of } 19 \text { families }(82 \%)\end{array}$ & HLA complex \\
\hline $\begin{array}{l}\text { Yamauchi } \\
\text { et al. }\end{array}$ & $\begin{array}{l}24 \text { Families } \\
\text { containing } \\
56 \text { patients } \\
\text { with MMD }\end{array}$ & Japanese & Linkage analysis & $\begin{array}{l}22 \text { Microsatellite } \\
\text { markers on } \\
\text { chromosome 17q25 }\end{array}$ & $17 q 25$ & $\begin{array}{l}\text { D17S939; } \\
\text { 9-cM region } \\
\text { between } \\
\text { D17S785 } \\
\text { and D17S836 }\end{array}$ & $\begin{array}{l}\text { D17S939: LOD score } \\
\text { of } 3.11 ; 9-c M \text { region } \\
\text { between D17S785 } \\
\text { and D17S836: } \\
\text { LOD scores up to } 4.58\end{array}$ & NF1 \\
\hline $\begin{array}{l}\text { Han } \\
\text { et al. }{ }^{38}\end{array}$ & $\begin{array}{l}28 \text { Moyamoya } \\
\text { patients versus } \\
198 \text { healthy } \\
\text { controls }\end{array}$ & Korean & $\begin{array}{l}\text { HLA phenotyping } \\
\text { and genotyping }\end{array}$ & $\begin{array}{l}\text { HLA alleles: } \\
\text { class I: HLA-A, HLA-B, } \\
\text { class II: HLA-DRB1, } \\
\text { DQA1, DQB1 }\end{array}$ & $6 p 21.3$ & HLA-B35 & $\begin{array}{l}\text { HLA-B35 associated } \\
\text { with MMD, } P<0.008\end{array}$ & HLA-B35 \\
\hline $\begin{array}{l}\text { Sakurai } \\
\text { et al. }{ }^{39}\end{array}$ & $\begin{array}{l}12 \text { Nuclear } \\
\text { families, } \\
\text { containing } \\
12 \text { affected } \\
\text { sibling pairs }\end{array}$ & Japanese & Linkage analysis & $\begin{array}{l}428 \text { Microsatellite } \\
\text { markers, genome-wide }\end{array}$ & $8 q 23,12 p 12$ & $\begin{array}{l}\text { D8S546, } \\
\text { D12S1690 }\end{array}$ & $\begin{array}{l}\text { 8q23 (D8S546): } \\
\text { MLS score 3.6; } \\
\text { 12p12 (D12S1690): } \\
\text { MLS score of } 2.3\end{array}$ & TIEG \\
\hline $\begin{array}{l}\text { Nanba } \\
\text { et al. }{ }^{40}\end{array}$ & $\begin{array}{l}1 \text { Affected } \\
\text { family with } \\
9 \text { members, } \\
4 \text { affected }\end{array}$ & Japanese & $\begin{array}{l}\text { Sequence analysis, } \\
\text { bioinformatics } \\
\text { (EST) }\end{array}$ & $\begin{array}{l}9 \text { Candidate genes } \\
\text { from the 9-cM region } \\
\text { between D17S785- } \\
\text { D17S836 in } \\
\text { chromosome 17q25 }\end{array}$ & None & None & $\begin{array}{l}\text { No MMD-related } \\
\text { variations were found }\end{array}$ & $\begin{array}{l}\text { DNAI2, AANAT, } \\
\text { PSR, HCNGP, } \\
\text { HN1, SGSH, } \\
\text { SYNGR2, EVPL, } \\
\text { TIMP2 }\end{array}$ \\
\hline $\begin{array}{l}\text { Kang } \\
\text { et al. }{ }^{41}\end{array}$ & $\begin{array}{l}11 \text { FMMD } \\
\text { patients versus } \\
50 \text { non-FMMD } \\
\text { patient controls, } \\
50 \text { healthy } \\
\text { controls }\end{array}$ & Korean & $\begin{array}{l}\text { Sequencing and } \\
\text { SNP analysis }\end{array}$ & $\begin{array}{l}\text { TIMP } 4 \text { and TIMP2 } \\
\text { on chromosomes } \\
\text { 3p24.2-p26 and 17q25 }\end{array}$ & $17 q 25$ & $\begin{array}{l}\text { (G/C) SNP in } \\
\text { the TIMP2 } \\
\text { promoter region, } \\
\text { position -418 } \\
\text { (rs8179090) }\end{array}$ & $\begin{array}{l}\text { FMMD versus non-FMMD: } \\
\text { OR=9.56, } \\
\text { CI95\%=1.85-49.48, } \\
P=0.005 ; \text { and } \\
\text { FMMD versus non-MMD: } \\
O R=10.50 \\
C I 95 \%=2.02-54.55 \\
P=0.001\end{array}$ & TIMP2, TIMP4 \\
\hline $\begin{array}{l}\text { Mineharu } \\
\text { et } a l .{ }^{47}\end{array}$ & $\begin{array}{l}15 \text { Highly } \\
\text { affected } \\
\text { families; } \\
52 \text { familial } \\
\text { MMD patients }\end{array}$ & Japanese & $\begin{array}{l}\text { Determination of } \\
\text { inheritance pattern } \\
\text { by studying affected } \\
\text { families }\end{array}$ & None & None & None & $\begin{array}{l}\text { Autosomal dominant } \\
\text { mode of inheritance } \\
\text { with incomplete } \\
\text { penetrance }\end{array}$ & None \\
\hline $\begin{array}{l}\text { Mineharu } \\
\text { et al. }{ }^{48}\end{array}$ & $\begin{array}{l}15 \text { Highly } \\
\text { affected } \\
\text { families; } \\
55 \text { familial } \\
\text { MMD patients }\end{array}$ & Japanese & $\begin{array}{l}\text { Genome-wide } \\
\text { parametric } \\
\text { linkage analysis }\end{array}$ & $\begin{array}{l}382 \text { Markers on all } \\
22 \text { autosomes and } \\
18 \text { on the X-chromosome }\end{array}$ & $17 q 25.3$ & $\begin{array}{l}\text { D17S704; } \\
\text { Candidate interval } \\
3.5 \mathrm{Mb} \text { between } \\
\mathrm{D} 17 \mathrm{~S} 1806 \text { and } \\
\text { the telomere } \\
\text { of } 17 \mathrm{q}\end{array}$ & $\begin{array}{l}\text { Maximum multipoint } \\
\text { LOD score of } 8.07 \\
\text { (broad classification) } \\
\text { and } 6.57 \text { (narrow } \\
\text { classification) at } \\
\text { chromosome } 17 q 25.3 \\
\text { (D17S704) }\end{array}$ & $\begin{array}{l}\text { BAIAP2, TIMP2, } \\
\text { RAC3, RAB40B }\end{array}$ \\
\hline $\begin{array}{l}\text { Guo } \\
\text { et al. }{ }^{49}\end{array}$ & $\begin{array}{l}20 \text { Families } \\
\text { ( } 127 \text { members) } \\
\text { with familial } \\
\text { TAAD, including } \\
\text { five patients } \\
\text { with MMD }\end{array}$ & $\begin{array}{l}\text { Northern } \\
\text { European }\end{array}$ & $\begin{array}{l}\text { Linkage analysis, } \\
\text { association studies, } \\
\text { sequencing }\end{array}$ & Whole genome, ACTA2 & $10 q 23.3$ & $\begin{array}{l}\mathrm{R} 258 \mathrm{H} / \mathrm{C} \\
\text { mutation in } \\
\text { exon } 7 \text { of ACTA2 }\end{array}$ & $\begin{array}{l}\text { Mutation at the } \\
\text { position R258H/C } \\
\text { in seven members } \\
\text { of three unrelated } \\
\text { families with early } \\
\text { onset stroke and MMD }\end{array}$ & ACTA2 \\
\hline
\end{tabular}


Table 1 Continued

\begin{tabular}{|c|c|c|c|c|c|c|c|c|}
\hline Author & Samples & Ethnicity & Type of study & Coverage & $\begin{array}{l}\text { Findings on } \\
\text { chromosome }\end{array}$ & Finding/marker & Result & Involved genes \\
\hline $\begin{array}{l}\text { Hong } \\
\text { et al. }{ }^{50}\end{array}$ & $\begin{array}{l}70 \text { Children } \\
\text { with MMD, } \\
\text { including } \\
16 \text { familial } \\
\text { cases (10 } \\
\text { probands) }\end{array}$ & Korean & $\begin{array}{l}\text { High-resolution } \\
\text { HLA genotyping }\end{array}$ & $\begin{array}{l}\text { HLA -DRB1 and } \\
\text { HLA-DQB1 }\end{array}$ & $6 p 21.3$ & $\begin{array}{l}\text { HLA-DRB1*1302, } \\
\text { HLA-DQB1*0609 }\end{array}$ & $\begin{array}{l}\text { HLA-DRB } 1 * 1302 \\
\text { and DQB1*0609 } \\
\text { significantly increased } \\
\text { in FMMD compared } \\
\text { with controls and } \\
\text { non-FMMD }\end{array}$ & HLA complex \\
\hline $\begin{array}{l}\text { Liu } \\
\text { et al. }{ }^{51}\end{array}$ & $\begin{array}{l}37 \text { Families } \\
\text { from Japan } \\
\text { and Korea; } \\
\text { 90Japanese, } \\
41 \text { Korean, } \\
23 \text { Chinese, } \\
25 \text { Caucasian } \\
\text { non-FMMD } \\
\text { samples }\end{array}$ & $\begin{array}{l}\text { Japanese, } \\
\text { Korean, } \\
\text { Chinese, } \\
\text { Caucasian }\end{array}$ & $\begin{array}{l}\text { Segregation analysis } \\
\text { followed by a case } \\
\text { control study on } \\
\text { one SNP }\end{array}$ & $\begin{array}{l}\text { Linkage: genome- } \\
\text { wide, as described } \\
\text { in Mineharu et al. } \\
\text { 2008; candidate } \\
\text { gene sequencing } \\
\text { on 17q25.3 } \\
\text { (CARD14, Raptor, } \\
\text { AATK, BAHCC1); } \\
\text { case-control study } \\
\text { on ss161110142 } \\
\text { G/A with non-FMMD }\end{array}$ & $17 q 25.3$ & $\begin{array}{l}\text { ss161110142 } \\
(\mathrm{G} / \mathrm{A}) \text { in the } \\
\text { Raptor gene }\end{array}$ & $\begin{array}{l}\text { LOD score increase } \\
\text { from } 8.07 \text { to } 9.67 \text { on } \\
17 q 25.3 \text {; increased } \\
\text { frequency of the rare } \\
\text { A allele in the Asian } \\
\text { cases with an odds } \\
\text { ratio of } 52.2(95 \% \mathrm{Cl} \text {, } \\
27.2-100.2) \\
\left(P=2.59 * 10^{\wedge}-49\right) \text { for } \\
\mathrm{ss} 161110142\end{array}$ & $\begin{array}{l}\text { CARD14, Raptor, } \\
\text { AATK, BAHCC1 }\end{array}$ \\
\hline $\begin{array}{l}\text { Roder } \\
\text { et al. }{ }^{52}\end{array}$ & $\begin{array}{l}40 \text { MMD } \\
\text { patients } \\
\text { versus } \\
68 \text { healthy } \\
\text { controls }\end{array}$ & $\begin{array}{l}\text { Central } \\
\text { European }\end{array}$ & $\begin{array}{l}\text { Candidate gene } \\
\text { association study }\end{array}$ & $\begin{array}{l}\text { SNPs in or adjacent } \\
\text { to BFGF, CRABP1, } \\
\text { PDGFRB, TGFB1 }\end{array}$ & $\begin{array}{l}5 q 31-q 32 \\
19 q 13.1\end{array}$ & $\begin{array}{l}\text { rs382861 (A/C) } \\
\text { in the promoter } \\
\text { region of PDGFRB, } \\
\text { rs1800471 [C/G] } \\
\text { in the first exon } \\
\text { of TGFB1 }\end{array}$ & $\begin{array}{l}\text { rs382861[A/C }] \\
(P=0.0373, \mathrm{OR}=1.81 \\
95 \% \mathrm{Cl}=1.03-3.17) \\
\text { rs1800471[C/G] } \\
(P=0.0345, \mathrm{OR}=7.65 \\
95 \% \mathrm{Cl}=0.97-59.95)\end{array}$ & PDGFRB, TGFB1 \\
\hline
\end{tabular}

Abbreviations: $\mathrm{Cl}$, confidence interval; EST, expressed sequence tag; FMMD, familial Moyamoya Disease; HLA, human leukocyte antigens; IBD, identity-by-descent; LOD, logarithm of odds score; MMD, MoyaMoya Disease; NPL, non-parametric linkage; OR, odds ratio; SNP, single-nucleotide polymorphism; TAAD, thoracic aortic aneurysms and dissection.

been described in more than 50 cases. ${ }^{20,33-36}$ The authors suggested that the neurofibromatosis type I protein is responsible for the growth of endothelial and smooth muscle cells in the ICA and their branches. Although this presumption could not be confirmed, several indications for a $M M D$ gene on Chromosome $17 q 25$ were found. Linkage analysis was performed with samples of 56 MMD patients from 24 families of Japanese descent. Two-point linkage analysis using a dominant transmission model gave a maximum LOD score (MLS) of 3.11 at the recombination fraction of 0.00 for the marker D17S939. Further examination of 22 microsatellite markers from the 9-cM region between D17S785 and D17S836 showed LOD scores up to 4.58 in multipoint linkage studies, making an association between MMD and $17 \mathrm{q} 25$ likely.

To confirm previous results ${ }^{25,37}$ for an association between HLA and MMD, Han et al. ${ }^{38}$ phenotyped and genotyped different HLA alleles in a Korean cohort of 28 Moyamoya patients and 198 unrelated healthy controls. HLA class I typing consisted of serological typing of HLA-A and -B, where positive results on HLA-B35 were confirmed by amplification refractory modification system-PCR. HLA class II typing was performed using the PCR-sequence specific oligonucleotide probe method, evaluating HLA-DRB1, HLA-DQA1 and HLA-DQB1. The results showed a statistically significantly increase in the frequency of the HLA-B35 allele in MMD patients compared with healthy controls (phenotype frequency: $32.1 \%$ in patients versus $10.1 \%$ in controls; relative risk $=4.2 ; P<0.008)$. Previous findings ${ }^{25,37}$ on $H L A-B 51$, $D R B 1^{\star} 0405, D Q B 1^{\star} 0502$ and $D Q B 1^{\star} 0401$ in a Japanese cohort could not be replicated in this study.

Sakurai et al. performed a genome-wide linkage analysis using 428 microsatellite markers in 12 nuclear families with MMD affected sib pairs (46 members). ${ }^{39}$ All patients (24) were Japanese and diagnosed with definite Moyamoya disease. The results showed significant evidence for linkage to chromosome 8q23 (D8S546) with a MLS of 3.6 and suggestive evidence for chromosome 12p12 (D12S1690) with a MLS of 2.3. This study also presented MLSs of 1.7, 1.6 and 1.3 for the formerly-described markers on chromosomes $3 p, 6 q$ and $7 q,{ }^{26,30,31}$ which was not enough to reach suggestive levels for linkage, probably a result of the small sample size in this study. Considering diseaserelated genes in the newly found regions with significant linkage, TIEG, transforming growth factor- $\beta$-inducible early growth response, located on $8 \mathrm{q} 22.3$, may be a possible candidate gene for MMD.

Sequence analysis of the 9-cM region between D17S785 and D17S836 on chromosome $17 \mathrm{q} 25$, which was described as a susceptibility region for a MMD gene by Yamauchi et al., ${ }^{31}$ was performed by Nanba et al. ${ }^{40}$ DNA was screened from one Japanese family with familial MMD (nine members, four affected), which showed a close linkage to $17 \mathrm{q} 25$ in a previous study. ${ }^{31}$ At the time of the study, 65 genes had been identified in this region, of which the authors picked nine to be sequenced: DNAI2, AANAT, PSR, HCNGP, HN1, SGSH, SYNGR2, EVPL and TIMP2. Sequence analysis could not detect any mutations related to MMD in the nine genes nor a novel candidate gene using the expressed sequence tag technique. Although there have been no MMD related findings, chromosome 17q25 remains a target for harboring a possible $M M D$ gene as linkage analysis narrowed down the susceptible region to $9 \mathrm{Mbs}$, of which only a small fraction has been analyzed.

Kang et al. investigated single-nucleotide polymorphism (SNP) and DNA sequences of exons, introns and promoter regions of the tissue inhibitor of metalloproteinase (TIMP) 2 and 4 genes, which are located on 3p24.2-p26 and 17q25, respectively. ${ }^{41}$ Both are hypothesized to harbor susceptible loci for MMD. ${ }^{26,31}$ The study was performed with the DNA of 11 Korean familial MMD (FMMD) patients, 50 non-FMMDpatients and 50 non-MMD controls. The most 
significant result of this study was the higher incidence of the G/C heterozygous genotype at position -418 of TIMP2 (GenBank reference sequence U44381/rs8179090; familial MMD versus non-FMMD: $\mathrm{OR}=9.56$, CI $95 \%=1.85-49.48, \quad P=0.005$; familial $\mathrm{MMD}$ versus non-MMD: $\mathrm{OR}=10.50, \mathrm{CI} 95 \%=2.02-54.55, P=0.001)$. The comparison of non-FMMD and non-MMD controls did not reveal significant differences. rs 8179090 is located at the third base of a Sp1 binding site in the promoter region of TIMP2, highlighting the suggestion that $17 q 25$ is a susceptibility locus for a MMD gene. TIMPs are proteins interacting with matrix metalloproteinases, in which malfunctioning may lead to changes in the extracellular matrix, erroneous smooth muscle cell-migration and -secretion into arterial walls. ${ }^{42}$ In addition to maintaining the extracellular matrix, TIMPs/MMPs also have major roles in vascular injury and repair. ${ }^{43-45}$ Shear stress is very high at the main locations of arterial thickening in MMD vessels, namely the terminal portions of the internal carotid artery. These regions are logical areas of constant repair, which might lead to intimal thickening in cases of gene product malfunction. ${ }^{46}$

Mineharu et al. analyzed 15 highly affected families with at least three MMD patients to determine the pattern of inheritance and clinical characteristics of familial MMD. ${ }^{47}$ A total of 52 FMMDs from Japan were included in the study. The results showed that FMMD is inherited by an autosomal dominant mode of transmission with incomplete penetrance.

In 2008, Mineharu et al. published the results of a parametric genome-wide linkage analysis (382 markers on 22 autosomes and 18 markers on the X-chromosome) of 15 Japanese families with 55 affected patients. ${ }^{48}$ Additionally, a total of 17 microsatellite markers were genotyped at $12.5-\mathrm{Mb}$ intervals at the $17 \mathrm{q} 25$-qter linkage region. Under a broad classification of MMD (including definite MMD, probable (unilateral) MMD and bilateral or unilateral steno-occlusive lesions around the terminal ICAs without Moyamoya vessels), a maximum multipoint LOD score of 8.07 was achieved, and under a narrow classification (definite Moyamoya disease) a MLS of 6.57 was achieved at chromosome 17q25.3 (D17S704). In 14 out of the 15 families, segregation of the disease haplotype was observed in all affected individuals. After defining the candidate interval to a distance of about $3.5 \mathrm{Mb}$ between D17S1806 and the telomere of $17 \mathrm{q}$ by an informative crossover and selecting four candidate genes (BAIAP2, TIMP2, RAC3, RAB40B) of 94 known genes in this region, a mutation analysis on one member of each of five families was performed, although there were no significant mutations related to MMD. The change in the TIMP2 promoter SNP at position -418 , which was significant in Korean MMD patients, ${ }^{41}$ could not be replicated in this study with Japanese MMD patients.

Guo et al. published the association of heterozygous mutations in ACTA2 in 20 families (127 members) with familial thoracic aortic aneurysms and dissection (TAAD). ${ }^{49}$ Exact phenotyping of these families revealed a high incidence of other vascular diseases, such as coronary artery disease, stroke or Moyamoya. In all, 5 of the 127 examined patients suffered early-onset stroke (between 5 and 46 years of age) secondary to Moyamoya. Genotyping revealed a common mutation at the position $\mathrm{R} 258 \mathrm{H} / \mathrm{C}$ in seven members of three unrelated families with early onset stroke and MMD, leading to the assumption that ACTA2 may be involved in the pathogenesis of MMD. All patients affected by MMD were of Northern European descent.

To clarify conflicting, previously published results on the association of MMD and HLA alleles, Hong et al. analyzed 70 Korean children, including 16 familial cases (10 probands) with MMD versus 207 healthy controls. ${ }^{50}$ Genotyping was performed for HLA-DRB1 and $H L A-D Q B 1$ genes using PCR-sequence specific oligonucleotide
(PCR-SSO) hybridization for intermediate resolution analysis and PCR-single strand conformation polymorphism for high-resolution analysis. The results showed that allele frequencies for HLA$D R B 1^{\star} 1302$ were significantly increased in familial MMD cases compared with controls (phenotype frequency familial MMD versus control $=70$ versus $15.5 \%, P_{\mathrm{c}}=0.008, \mathrm{OR}=12.76$ ), and compared with sporadic MMD cases (phenotype frequency familial MMD versus control $=70$ versus $14.8 \%, P_{\mathrm{c}}=0.02, \mathrm{OR}=13.42$ ). Allele frequencies for $H L A$ $D Q B 1{ }^{*} 0609$ also showed significant differences between familial MMD cases and controls (phenotype frequency familial MMD versus control $=40$ versus $4.3 \%, P_{c}=0.02, \mathrm{OR}=14.67$ ), as well as sporadic cases (phenotype frequency familial MMD versus control $=70$ versus $1.9 \%$, $P_{\mathrm{c}}=0.02, \mathrm{OR}=35.33$ ). No significant differences between sporadic MMD cases and controls were found for HLA-DRB1 and HLA-DQB1.

In 2009, Liu et al. expanded their 2008 linkage analysis with two Japanese families, increasing the LOD score from 8.07 to 9.67 for 17q25.3. ${ }^{51}$ This region contains 40 genes, of which four (CARD14, Raptor, AATK, BAHCC1) were chosen for sequencing in four unrelated, affected individuals. The polymorphism ss161110142 G/A in the Raptor gene (position - 1480 from the transcription site of the Raptor gene) appeared to be of interest because all four sequenced affected individuals were found to be heterozygous for the risk allele. This SNP was genotyped in 34 families showing that every affected individual carried the rare A allele. All affected individuals showed complete segregation, and the two-point LOD score was $14.2\left(P=3.89 \times 10^{-8}\right)$. In the final stage, case-control studies in Japanese ( 90 cases versus 384 controls), Korean (41 cases versus 223 controls), Chinese (23 cases versus 100 controls), and Caucasian (25 cases versus 164 controls) patients with non-FMMD were performed with genotyping data for the SNP ss161110142. The rare allele (A) was much more frequent in cases versus controls (26:1 Japanese, 33:1 Korean, 4:0 Chinese) and was significantly associated with an increased odds ratio of $52.2(95 \%$ $\left.\mathrm{CI}=27.2-100.2, P=2.59 \times 10^{-49}\right)$. However, the rare A allele was not detected in the Caucasian samples. Furthermore, Liu et al. found a possible founder haplotype spanning $65 \mathrm{kbp}$ common to Japanese and Korean cases.

The first study on a European MMD cohort was published by Roder et al. in $2010 .^{52}$ An association study of 13 SNPs in or adjacent to four candidate genes (BFGF, CRABP1, PDGFRB, TGFB1) chosen based on histopathological changes seen in Moyamoya vessels, was conducted with DNA samples of 40 MMD patients and 68 healthy controls. All participants were from Central Europe, primarily Germany and Switzerland. Association with MMD was demonstrated for two SNPs: rs1800471 (C/G) located in the first exon of TGFB1 $(P=0.0345, \mathrm{OR}=7.65,95 \% \mathrm{CI}=0.97-59.95)$ and $\mathrm{rs} 382861(\mathrm{~A} / \mathrm{C})$ in the promoter region of $P D G F R B(P=0.0373, \quad O R=1.81,95 \%$ $\mathrm{CI}=1.03-3.17)$.

\section{CONCLUDING REMARKS}

MMD is a cerebrovascular disease causing severe neurological dysfunction or death if not recognized and treated appropriately. Aside from certain environmental factors, such as radiation or infection in the head and neck, the etiology of MMD is still unknown. The concentration of affected patients in Asian countries, as well as published familial cases strengthens the hypothesis that genetics have a role in the development of the disease. Genetic studies have been performed in Japanese and Korean cohorts without convincing evidence for a genetic basis, and while linkage studies have suggested $17 q 25$ as a region of interest, subsequent attempts to identify a single causal gene have failed. Genome-wide association studies may bring additional knowledge of disease causing genes in the general 
population through the identification of susceptible SNPs via casecontrol studies of unrelated individuals. Additionally, analysis of other vascular diseases, which may share common pathways with MMD, might also be helpful, as demonstrated in the reported genetic findings on thoracic aortic aneurysms and dissection and MMD by Guo et al. ${ }^{49}$

Nevertheless, the rarity of MMD and likely multifactorial nature of the disease poses a tremendous challenge in the search for a diseasecausing gene. Moving forward, larger, multicenter studies using current genotyping approaches would help to achieve greater statistical power needed to discover susceptibility alleles, but ultimately next generation sequencing technologies will become the gold standard to identify causal mutation and hence a better understanding of the underlying pathogenesis of Moyamoya disease.

1 Takeuchi, K. \& Shimizu, K. Hypoplasia of the bilateral internal carotid arteries. Brain Nerve. 9, 37-43 (1957).

2 Suzuki, J. \& Takaku, A. Cerebrovascular 'moyamoya' disease. Disease showing abnormal net-like vessels in base of brain. Arch. Neurol. 20, 288-299 (1969).

3 Fukui, M. Guidelines for the diagnosis and treatment of spontaneous occlusion of the circle of Willis ('moyamoya'disease). Research Committee on Spontaneous Occlusion of the Circle of Willis (Moyamoya Disease) of the Ministry of Health and Welfare, Japan. Clin. Neurol. Neurosurg. 99, S238 (1997).

4 Yonekawa, Y. \& Taub, E. Moyamoya disease: status 1998. Neurologist. 5, 13-23 (1999).

5 Khan, N. \& Yonekawa, Y. Moyamoya angiopathy in Europe: 'The Zürich experience'. Stroke Rev. 9, 181-188 (2005).

6 Uchino, K., Johnston, S. C., Becker, K. J. \& Tirschwell, D. L. Moyamoya disease in Washington state and California. Neurology. 65, 956-958 (2005).

7 Baba, T., Houkin, K. \& Kuroda, S. Novel epidemiological features of moyamoya disease. Br. Med. J. 79, 900-904 (2008).

8 Wakai, K., Tamakoshi, A., Ohno, Y., Kawamura, T., Ikezaki, K. \& Fukui, M. Epidemiology of spontaneous occlusion of the circle of Willis: results of national epidemiologic survey. The Research Committee on Spontaneous Occlusion of the Circle of Willis (Moyamoya Disease) of the Ministry of Health and Welfare Japan: Annual Report 1995 33-37 (1995).

9 Fukui, M. Current state of study on moyamoya disease in Japan. Surg. Neurol. 47, 138-143 (1997).

10 Ikezaki, K., Han, D. H., Kawano, T., Kinukawa, N. \& Fukui, M. A clinical comparison of definite moyamoya disease between South Korea and Japan. Stroke 28, 2513-2517 (1997).

11 Iwama, T. \& Yoshimura, S. Present status of Moyamoya disease in Japan. Acta. Neurochir. (Wien). 103, 115-118 (2008).

12 Scott, R. M. \& Smith, E. R. Moyamoya disease and Moyamoya syndrome. N. Engl. J. Med. 360, 1226-1237 (2009).

13 Ikezaki, K. Rational approach to treatment of Moyamoya disease in childhood. J. Child Neurol. 15, 350-356 (2000)

14 Khan, N., Schuknecht, B., Boltshauser, E., Capone, A., Buck, A., Imhof, H. et al. Moyamoya disease and Moyamoya syndrome: experience in Europe; choice of revascularisation procedures. Acta. Neurochir. (Wien). 145, 1061-1071 (2003).

15 Matsushima, Y., Aoyagi, M., Suzuki, R., Nariai, T., Shishido, T. \& Hirakawa, K. Dual anastomosis for pediatric moyamoya patients using the anterior and the posterior branches of the superficial temporal artery. Nerv. Syst. Child. 18, 27-32 (1993).

16 Takagi, Y., Kikuta, K., Nozaki, K. \& Hashimoto, N. Histological features of middle cerebral arteries from patients treated for Moyamoya disease. Neurol. Med. Chir. (Tokyo). 47, 1-4 (2007).

17 Ullrich, N. J., Robertson, R., Kinnamon, D. D., Scott, R. M., Kieran, M. W., Turner, C. D. et al. Moyamoya following cranial irradiation for primary brain tumors in children. Neurology. 68, 932-938 (2007).

18 Yamada, H., Deguchi, K., Tanigawara, T., Takenaka, K., Nishimura, Y., Shinoda, J. et al. The relationship between Moyamoya disease and bacterial infection. Clin. Neurol. Neurosurg. 99, S221 (1997).

19 Fukuyama, S., Kanai, M. \& Osawa, M. Clinical genetic analysis on the Moyamoya disease. The Research Committee on Spontaneous Occlusion of the Circle of Willis (Moyamoya Disease) of the Ministry of Health and Welfare Japan: Annual report 1990 53-59 (1990).

20 Osawa, M., Kanai, N., Kawai, M. \& Fukuyama, Y. Clinical genetic study on the idiopathic occlusion of the circle of Willis. The research committee on spontaneous occlusion of the circle of Willis (Moyamoya disease) of the Ministry of Health and Welfare in Japan. Annual Report Tokyo, Japan: Ministry of Health and Welfare, Japan 147-152 (1992).

21 Yamauchi, T., Houkin, K., Tada, M. \& Abe, H. Familial occurrence of moyamoya disease. Clin. Neurol. Neurosurg. 99, 159-164 (1997).

22 Nanba, R., Kuroda, S., Tada, M., Ishikawa, T., Houkin, K. \& Iwasaki, Y. Clinical features of familial moyamoya disease. Childs Nerv. Syst. 22, 258-262 (2006).
23 Kuroda, S. \& Houkin, K. Moyamoya disease: current concepts and future perspectives. Lancet. Neurol. 7, 1056-1066 (2008).

24 Smith, E. R. \& Scott, R. M. Surgical management of moyamoya syndrome. Skull Base. 15,15 (2005)

25 Inoue, T. K., Ikezaki, K., Sasazuki, T., Matsushima, T. \& Fukui, M. Analysis of class II genes of human leukocyte antigen in patients with Moyamoya disease. Clin. Neurol. Neurosurg. 99, S229-S232 (1997).

26 Ikeda, H., Sasaki, T., Yoshimoto, T., Fukui, M. \& Arinami, T. Mapping of a familial moyamoya disease gene to chromosome 3p24. 2-p26. Am. J. Hum. Genet. 64, 533-537 (1999).

27 Collod, G., Babron, M. C., Jondeau, G., Coulon, M., Weissenbach, J., Dubourg, O. et al. A second locus for Marfan syndrome maps to chromosome 3p24. 2-p25. Nat. Genet. 8, 264 (1994).

28 Latif, F., Tory, K., Gnarra, J., Yao, M., Duh, F. M., Orcutt, M. L. et al. Identification of the von Hippel-Lindau disease tumor suppressor gene. Science. 260, 1317-1320 (1993).

29 Inoue, T. K., Ikezaki, K., Sasazuki, T., Ono, T., Kamikawaji, N., Matsushima, T. et al. DNA typing of HLA in the patients with moyamoya disease. J. Hum. Genet. 42, 507-515 (1997).

30 Inoue, T. K., Ikezaki, K., Sasazuki, T., Matsushima, T. \& Fukui, M. Linkage analysis of moyamoya disease on chromosome 6. J. Child Neurol. 15, 179-182 (2000).

31 Yamauchi, T., Tada, M., Houkin, K., Tanaka, T., Nakamura, Y., Kuroda, S. et al. Linkage of familial moyamoya disease (spontaneous occlusion of the circle of willis) to chromosome 17q25. Stroke. 31, 930-935 (2000).

32 Xu, G. F., O'Connell, P., Viskochil, D., Cawthon, R., Robertson, M., Culver, M. et al. The neurofibromatosis type 1 gene encodes a protein related to GAP. Cel/ 62, 599-608 (1990).

33 Barrall, J. L. \& Summers, C. G. Ocular ischemic syndrome in a child with moyamoya disease and neurofibromatosis. Surv. Ophthalmol. 40, 500-504 (1996).

34 Edwards Brown, M. K. \& Quets, J. P. Midwest experience with moyamoya disease. Clin. Neurol. Neurosurg. 99, 36-38 (1997).

35 Woody, R. C., Perrot, L. J. \& Beck, S. A. Neurofibromatosis cerebral vasculopathy in an infant: clinical, neuroradiographic, and neuropathologic studies. Fetal. Pediatr. Pathol. 12, 613-619 (1992)

36 Kwong, K. L. \& Wong, Y. C. Moyamoya disease in a child with neurofibromatosis type-1. J. Paediatr. Child Health. 35, 108-109 (1999).

37 Aoyagi, M., Ogami, K., Matsushima, Y., Shikata, M., Yamamoto, M. \& Yamamoto, K. Human leukocyte antigen in patients with Moyamoya disease. Stroke. 26, 415-417 (1995).

38 Han, H., Pyo, C., Yoo, D., Huh, P., Cho, K. \& Kim, D. Associations of Moyamoya patients with HLA class I and class II alleles in the Korean population. J. Korean Med. Sci. 18, 876-880 (2003).

39 Sakurai, K., Horiuchi, Y., Ikeda, H., Ikezaki, K., Yoshimoto, T., Fukui, M. et al. A novel susceptibility locus for moyamoya disease on chromosome 8q23. J. Hum. Genet. 49, 278-281 (2004).

40 Nanba, R., Tada, M., Kuroda, S., Houkin, K. \& Iwasaki, Y. Sequence analysis and bioinformatics analysis of chromosome 17q25 in familial moyamoya disease. Childs Nerv. Syst. 21, 62-68 (2005).

41 Kang, H. S., Kim, S. K., Cho, B. K., Kim, Y. Y., Hwang, Y. S. \& Wang, K. C. Single nucleotide polymorphisms of tissue inhibitor of metalloproteinase genes in familial moyamoya disease. Neurosurgery. 58, 1074-1080 (2006).

42 Johnson, C. \& Galis, Z. S. Matrix metalloproteinase-2 and -9 differentially regulate smooth muscle cell migration and cell-mediated collagen organization. Arterioscler. Thromb. Vasc. Biol. 24, 54 (2004).

43 Dollery, C. M., McEwan, J. R., Wang, M., Sang, Q. A., Liu, Y. E. \& Shi, Y. E. TIMP-4 is regulated by vascular injury in rats. Ann. N. Y. Acad. Sci. 84, 498-504 (1999).

44 Hasenstab, D., Forough, R. \& Clowes, A. W. Plasminogen activator inhibitor type 1 and tissue inhibitor of metalloproteinases-2 increase after arterial injury in rats. Circ. Res. 80, 490-496 (1997).

45 Shi, Y., Patel, S., Niculescu, R., Chung, W., Desrochers, P. \& Zalewski, A. Role of matrix metalloproteinases and their tissue inhibitors in the regulation of coronary cell migration. Arterioscler. Thromb. Vasc. Biol. 19, 1150-1155 (1999).

46 Paszkowiak, J. J. \& Dardik, A. Arterial wall shear stress: observations from the bench to the bedside. Vasc. Endovascular Surg. 37, 47 (2003).

47 Mineharu, Y., Takenaka, K., Yamakawa, H., Inoue, K., Ikeda, H., Kikuta, K. I. et al. Inheritance pattern of familial moyamoya disease: autosomal dominant mode and genomic imprinting. J. Neurol. Neurosurg. Psychiatry. 77, 1025-1029 (2006).

48 Mineharu, Y., Liu, W., Inoue, K., Matsuura, N., Inoue, S., Takenaka, K. et al. Autosomal dominant moyamoya disease maps to chromosome 17q25.3. Neurology. 70, 2357-2363 (2008)

49 Guo, D.- C., Papke, C. L., Tran-Fadulu, V., Regalado, E. S., Avidan, N., Johnson, R. J. et al. Mutations in smooth muscle alpha-actin (ACTA2) cause coronary artery disease, stroke, and moyamoya disease, along with thoracic aortic disease. Am. J. Hum. Genet. 84, 617-627 (2009).

50 Hong, S., Wang, K., Kim, S., Cho, B. \& Park, M. Association of HLA-DR and-DQ genes with familial moyamoya disease in Koreans. J. Korean Neurosurg. Soc. 46, 558-563 (2009).

51 Liu, W., Hashikata, H., Inoue, K., Matsuura, N., Mineharu, Y., Kobayashi, H. et al. A rare Asian founder polymorphism of RAPTOR may explain the high prevalence of moyamoya disease among East Asians and its low prevalence among Caucasians. Env. Health Prev. Med. 1-11 (2009).

52 Roder, C., Peters, V., Kasuya, H., Nishizawa, T., Takehara, Y., Berg, D. et al. Polymorphisms in TGFB1 and PDGFRB are associated with Moyamoya disease in European patients. Acta. Neurochir. (Wien). (2010). (e-pub ahead of print 23 June 2010; DOI 10.1007/s00701-00010-00711-00709). 